worthy. The average transmission of the lunar rays by glass during the eclipse was about twenty-two per cent, and did not differ very materially from that for the uneclipsed moon on this day. If the increased transmissibility at the outer edge of the umbra be a real effect, it is possibly local and evanescent.

The deflection obtained from a portion of the lunar surface just in advance of the umbra did not very materially differ from that given by a similar portion over which the umbra had just passed.

Clouds, preventing further observations, began to form as the penumbra was about passing off. There were indications, however, of a recovery of heat nearly as rapid as the previous fall. This effect was shown, though in a less marked manner, by $\mathrm{Dr}$. Boeddicker's observations, in the eclipse of Oct. 4, 1884, made at Lord Rosse's observatory (see Nature, xxx. p. 589).

The following are the deflections observed on each point during the progress of the eclipse at Allegheny :

\begin{tabular}{|c|c|c|c|c|c|c|c|c|c|c|c|}
\hline & 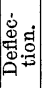 & 毘 & $\begin{array}{c}\text { Time } \\
\text { from } \\
\text { mid- } \\
\text { eclipse. }\end{array}$ & & 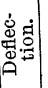 & $\underset{\mid g}{g}$ & $\begin{array}{c}\text { Time } \\
\text { from } \\
\text { mid- } \\
\text { eclipse. }\end{array}$ & & 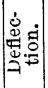 & $\underset{\Xi}{\stackrel{\Xi}{\mid \Xi}}$ & $\begin{array}{c}\text { Time } \\
\text { from } \\
\text { mid- } \\
\text { eclipse }\end{array}$ \\
\hline $\begin{array}{l}\text { East } \\
\text { “، } \\
\text { N.E. } \\
\text { S. E. }\end{array}$ & $\begin{array}{r}164 \\
125 \\
45 \\
4 \\
71\end{array}$ & $\begin{array}{r}\text { h. } \mathrm{m} . \\
11.53 \\
12.26 \\
12.53 \\
1.28 \\
3.43\end{array}$ & $\begin{array}{l}\text { b. } \mathrm{m} . \\
2.35 \\
2.28 \\
1.35 \\
1.00 \\
1.15\end{array}$ & $\begin{array}{c}\text { Cen } \\
\text { tre. } \\
66 \\
6 \\
6\end{array}$ & $\begin{array}{r}180 \\
128 \\
101 \\
31\end{array}$ & $\begin{array}{r}\text { h. m. } \\
12.01 \\
12.44 \\
1.06 \\
3.49\end{array}$ & $\begin{array}{c}\mathrm{h} . \mathrm{m} . \\
2.27 \\
1.44 \\
1.22 \\
1.21\end{array}$ & $\begin{array}{c}\text { W est } \\
\because 6 \\
u\end{array}$ & $\begin{array}{r}155 \\
153 \\
129 \\
21\end{array}$ & $\begin{array}{r}\text { b. m. } \\
12.16 \\
12.32 \\
12.58 \\
4.05\end{array}$ & $\begin{array}{r}\mathrm{h} . \mathrm{m} . \\
212 \\
1.56 \\
1.30 \\
1.37\end{array}$ \\
\hline
\end{tabular}

The salient feature of these observations is, we need hardly say, the extraordinary rapidity with which the lunar surface parts with its heat, most of that which is radiated disappearing all but simultaneously with that reflected.

Allegheny observatory, Lec. 23.

\section{Sir William Thomson to the coefficients.}

I know of no easier way to reach those for whom the enclosed message was especially intended than through the columns of Science. At the same time, I believe it will be read with great interest by many who were not of the somewhat limited number referred to. To such, a brief explanation may be due :-

At the close of the course of lectures by Sir William Thomson, at Baltimore, in October, 1884, it was determined by those who, through the courtesy of the Johns Hopkins university, had enjoyed the privilege of listening to the course, to present Sir William with a memento of the occasion which had been, to them, of such unusual interest. Under the circumstances, nothing could have been more fitting for this purpose than one of Professor Rowland's large concave gratings, which was accordingly agreed upon. Several months were required for the manufacture and examination of a grating which was entirely satisfactory to Professor Rowland; but early in the past summer it was completed, and transmitted to Sir William Thomson through the kindness of the secretary of the Smithsonian institution.

Prof. George Forbes of London was present during the course of lectures, and Lord Rayleigh attended a number of them. In the equations of motion developed in the work there appeared twenty-one coefficients, agreeing in number nearly, if not exactly, with the number of persons in regular attendance upon the lectures. This relation was quickly noticed by some one, and was made the basis of some humorous verses composed by the genial and witty Forbes, which were read at a reception given to the class by President Gilman, and were afterward published. Their title was "The lament of the twenty-one coefficients in parting from each other and from their much-esteemed molecule."

The first stanza began, -

"An aeolotropic molecule was looking at the view,

Surrounded by his coefficients, twenty one or two;"

and the whole will always possess much interest to those who were present. With this explanation, I justify the title which I have given to the following selections from a letter recently received from Sir William Thomson.

T. C. M.

Washington, D.C., Dec. 28.

I wrote to Professor Rowland, acknowledging the receipt of the grating; but I ought before now to have thanked all the other coefficients for their kindness in giving it to me. I should feel greatly obliged if you would transmit to those of the coefficients who are in America my heartiest thanks for their great kindness, and say to them that the grating will be a permanent memorial to me of the happy three weeks of 1884, when we were together in Baltimore. . . . After the British association meeting at Aberdeen, I was delighted to be able to show the grating to some of our English appreciators, - including one of the coefficients, George Forbes ; and Lord Rayleigh, whom we may consider as, at all events, a partial coefficient; and Professor Fitzgerald of Trinity college, Dublin ; Oliver Lodge of Liverpool ; Glazebrooke of Cambridge; and Captain Creak of the compass department of our admiralty, - who came to stay with us at Netherhall, our country house, for a few days, on their way south. We had no sunlight to work with, but we got the double sodium light in the first and second spectrums from a salted spirit-lamp flame exceedingly well, and we were all delighted with the result. I had never myself seen any thing like it before. WILLIAM THOMSON.

The university, Glasgow, Dec. 5,

\section{A waste of public money.}

My attention has just been drawn to your notice in Science of Dec. 4, of my forthcoming report on irrigation. The substance of your criticism is that quantity, and not quality, appears to have been the object in its compilation, - that the work should have been written in one volume instead of three; and you quote a long, redundant paragraph as a sample of the composition throughout.

It is to be regretted that you undertook to criticise an entire report, when you had before you only some advance sheets of one volume, very hastily printed from unrevised manuscript, solely for the purpose of an exhibit to the legislature, which desired to know something of the scope of the work.

The entire report, as ordered printed, is now under way; and I believe you will find, when you receive a copy, a decided improvement in the literary construction which you have criticised. As for the general make-up of the work, - its fulness, and occasional repetition of matter under different headings, -- which you do not specially refer to, but probably have noticed, I shall have something to say at the 